\title{
Analisis Literatur Teknologi dalam Integrasi Pendidikan STEM pada Pembelajaran IPA
}

\author{
Andinisa Rahmaniar ${ }^{1 *}$, dan Abdul Latip ${ }^{2}$ \\ $1^{*}, 2$ Program Studi Pendidikan IPA, Universitas Garut \\ Jl. Raya Samarang No.52A Hampor Desa Mekarwangi Kecamatan Tarogong Kaler, Kabupaten Garut, Jawa \\ Barat 44151 \\ ‘E-mail Penulis Korespondensi: andinisa@uniga.ac.id
}

\begin{abstract}
Abstrak
Pada abad 21, peserta didik dituntut memiliki kemampuan abad 21, seperti berpikir kritis, kreatif, inovatif, dan berkolaborasi. Kemampuan ini dapat dikembangkan dalam pembelajaran STEM yang diintegrasikan di pelajaran IPA. Dalam penerapannya, semua bidang kajian STEM dikombinasikan untuk menyelesaikan masalah pada kehidupan nyata, salah satunya yaitu penggunaan teknologi. Penulisan artikel ini bertujuan melakukan analisis secara kajian literatur mengenai analisis penggunaan teknologi dalam integrasi pendidikan STEM. Metode penelitian yang digunakan adalah literature review yang menganalisis penelitian sebelumnya untuk mengetahui penggunaan teknologi dalam pembelajaran IPA yang terintegrasi Pendidikan STEM. Berdasarkan hasil analisis dari beberapa penelitian diperoleh hasil: 1) teknologi digunakan sebagai media pendukung pembelajaran STEM untuk mencapai kompetensi pelajaran IPA; 2) teknologi yang digunakan dapat meningkatkan kemampuan abad 21, seperti berpikir kritis, kreatif, inovatif, dan kolaborasi; 3) teknologi dapat mengembangkan keterampilan saintifik yaitu mengumpulkan informasi. Hasil tersebut menunjukkan bahwa penggunaan teknologi dalam integrasi STEM memiliki peran yang penting dalam pembelajaran IPA. Sehingga, teknologi bukan hanya sebagai media tetapi dapat dimanfaatkan sebagai salah satu kompetensi yang perlu dimiliki peserta didik.
\end{abstract}

Kata kunci: STEM, IPA, teknologi, kemampuan abad 21

\section{Abstract}

In the 21st century, learners are required to have 21st-century skills, such as critical thinking, creativity, innovation, and collaboration. This ability can be developed in STEM learning integrated into science lessons. In its application, all STEM studies are combined to solve real-life problems, one of which is the use of technology. The research method used is a literature review where there are four articles analyzed to find out how far the use of technology in learning science integrated STEM Education. Based on the results of analysis from several studies, technology is used as a supporting medium for STEM learning to achieve science lesson competencies. In addition, the technologies used can enhance 21st-century capabilities, such as critical thinking, creativity, innovation, and collaboration. The other result is to develop scientific skills, namely collecting information

.Keywords: STEM, science, technology, $21^{\text {st }}$-century skills

\section{Article History: Received: 15 Oktober 2021}

Accepted: 25 November 2021

\section{Revised : 23 November 2021}

Published: 30 November 2021

How to cite: Rahmaniar, A, Latip, A. (2021). Analisis Literatur Teknologi dalam Integrasi Pendidikan STEM pada Pembelajaran IPA, Jurnal Literasi Pendidikan Fisika, 2 (2). pp. 143-148. Retrieved from http://jurnal.fkip.unmul.ac.id/index.php/JLPF

Copyright (C) November 2021, Jurnal Literasi Pendidikan Fisika 
Analisis Literatur Teknologi...

\section{PENDAHULUAN}

Pada abad 21 ini, peserta didik dituntut untuk memiliki kemampuan abad 21 yaitu 4C (collaboration, critical thinking, creative, and communication) seperti kemampuan pemecahan masalah, berpikir kritis, dan berkolaborasi. Kemampuan ini dapat mereka miliki selama pembelajaran di kelas, salah satunya melalui Pendidikan STEM dimana empat kemampuan tersebut merupakan karakteristik dari pembelajaran STEM (Milaturrahman dkk., 2017).

Pendidikan STEM adalah suatu kurikulum yang mengintegrasikan empat subjek (Science, Technology, Engineering, and Mathematics) dalam menyelesaikan masalah di kehidupan nyata (Rahmaniar, 2020). Selain itu, pada pembelajaran STEM, siswa mengelaborasi konsep, prinsip, dan teknis dari sains, teknologi, matematika dalam integrasi pembuatan produk, proses dan sistem yang bermanfaat bagi kehidupan (Wilson, 2019)

Pendidikan STEM di Indonesia telah mulai dikembangkan oleh para pendidik baik di tingkat sekolah dasar ataupun menengah. Namun, Pendidikan STEM masih banyak diterapkan sebagai salah satu metode pembelajaran bukan sebagai kurikulum yang terintegrasi. Hal ini dikarenakan Indonesia mempunyai kurikulum Nasional yang harus diterapkan oleh semua sekolah, sehingga sekolah tidak bisa mengembangkan kurikulum berdasarkan keperluannya (Rahmaniar, 2020).

Menurut penelitian yang dilakukan oleh Rahmaniar (2020), penerapan Pendidikan STEM di Indonesia menghadapi beberapa hambatan, salah satunya adalah keterbatasan teknologi untuk mendukung pembelajaran IPA khususnya yang terintegrasi STEM. Banyak yang beranggapan bahwa Pendidikan STEM selalu berhubungan dengan teknologi yang canggih.

Menurut (Banks et al., 2014), penggunaan IT di sekolah diklasifikasikan menjadi lima model, yang pertama sebagai alat demostrasi dan ilustrasi, sebagai bagian dari aktivitas kelas, digunakannya enam komputer untuk setengah kelas, seluruh kelas menggunakan komputer, setiap peserta didik menggunakan komputer sebagai penggunaan pribadi. Mereka juga menjelaskan bahwa penggunaan teknologi dapat dielaborasikan dengan bidang STEM lainnya, seperti sains, engineering, dan matematika. Salah satu contoh penggunaan teknologi yang dipaparkan oleh Banks dan Barlex adalah VLE (Virtual Learning Environment) yang merupakan platform untuk pelaksanaan pembelajaran jarak jauh. Peserta didik dan orang tua dapat mengakses materi pelajaran pada platform pembelajaran yang disediakan setiap sekolah.

Terdapat penelitian sebelumnya yang meneliti mengenai penggunaan teknologi dalam pembelajaran STEM baik secara online ataupun tatap muka. Ada penelitian yang memanfaatkan pembelajaran berbasis permainan (PBP) digital oleh (Weng et al., 2018)) yang menyebutkan bahwa PBP ini mampu meningkatkan kemampuan abad 21. Selain itu, penelitian yang dilakukan oleh (Ismail et al., 2016) dalam menggunakan virtual lab untuk meningkatkan literasi digital. Selanjutnya, penelitian yang dilakukan (Asri et al., 2021) dilakukan untuk menganalisis pembelajaran STEM pada pembelajaran jarak jauh. Penelitian lainnya dilakukan oleh (Agung et al., 2018) yang bertujuan untuk menganalisis peningkatan keterampilan ilmiah pembelajaran fisika melalui penerapan STEM dan elearning.

Berdasarkan penelitian tersebut, sebenarnya teknologi sudah diimplementasikan dalam ruang lingkup aktivitas peserta didik. Namun, belum ada penjelasan sudah sejauh mana teknologi diterapkan dalam pembelajaran IPA yang terintegrasi STEM. Oleh sebab itu, penelitian ini bertujuan untuk menganalisis pemanfaatan teknologi dalam pembelajaran IPA yang terintegrasi Pendidikan STEM. Penelitian ini juga memberikan kontribusi dalam pengembangan pemanfaatan teknologi sebagai salah satu kompetensi yang perlu dicapai pada pembelajaran IPA melalui penerapan pendidikan STEM.

\section{METODE}

Metode yang digunakan dalam penelitian ini yaitu analisis literatur dengan 4 langkah literature 
Analisis Literatur Teknologi...

review, yaitu pemilihan topik yang akan direview, mencari dan menyeleksi artikel yang berkaitan dengan topik, menganalisis dan menyintesis literatur, dan mengorganisasikan tulisan (Ramdhani, Ramdhani, \& Amin, 2014). Artikel yang dianalisis berasal dari berbagai sumber, seperti Google Scholar. Terdapat lima artikel yang dianalisis, yaitu satu penelitian mengenai penggunaan teknologi di sekolah, dan empat artikel mengenai pemanfaatan teknologi dalam pembelajaran STEM, seperti yang dapat dilihat pada Tabel 1. Hasil analisis akan dielaborasikan dengan literatur terkait penggunaan teknologi dalam pembelajaran STEM dan mengenai Pendidikan STEM. Sehingga, diperoleh hasil untuk menjawab rumusan masalah penelitian ini yaitu bagaimana pemanfaatan teknologi dalam pembelajaran STEM.

Tabel 1 Bahan Kajian Artikel yang dianalisis

\begin{tabular}{|c|c|c|c|c|c|}
\hline No. & Penulis & Bidang Kajian & Materi & Tingkat Sekolah & $\begin{array}{c}\text { Penggunaan } \\
\text { Teknologi }\end{array}$ \\
\hline 1 & $\begin{array}{l}\text { Wong Weng Siong } \\
\text { dan Kamisah } \\
\text { Osman }\end{array}$ & $\begin{array}{l}\text { Pemanfaatan permainan } \\
\text { dalam Pendidikan STEM }\end{array}$ & $\begin{array}{l}\text { Sains (Kimia, } \\
\text { Fisika, dan } \\
\text { Biologi) }\end{array}$ & Pre-Universitas & $\begin{array}{l}\text { Pembuatan } \\
\text { permainan } \\
\text { digital dalam } \\
\text { Pendidikan } \\
\text { STEM }\end{array}$ \\
\hline 2 & $\begin{array}{l}\text { Ismail, Anna } \\
\text { Permanasari, } \\
\text { Wawan Setiawan }\end{array}$ & $\begin{array}{l}\text { Virtual lab dalam } \\
\text { meningkatkan literasi } \\
\text { digital }\end{array}$ & $\begin{array}{l}\text { Sistem } \\
\text { Pencernaan }\end{array}$ & $\begin{array}{l}\text { Sekolah } \\
\text { Menengah } \\
\text { pertama }\end{array}$ & $\begin{array}{l}\text { Penggunaan } \\
\text { Virtual Lab }\end{array}$ \\
\hline 3 & $\begin{array}{l}\text { Yoana Nurul Asri, } \\
\text { Desta Sulaesih } \\
\text { Mursyidah, dan Vini } \\
\text { Rizqi }\end{array}$ & $\begin{array}{l}\text { Pendekatan STEM dalam } \\
\text { pembelajaran jarak jauh }\end{array}$ & Kelistrikan & $\begin{array}{l}\text { Sekolah } \\
\text { Menengah Atas }\end{array}$ & $\begin{array}{l}\text { Penggunaan } \\
\text { video } \\
\text { pembelajaran }\end{array}$ \\
\hline 4 & $\begin{array}{l}\text { I Gusti Agung } \\
\text { Wisnu }\end{array}$ & $\begin{array}{l}\text { Keterampilan Ilmiah } \\
\text { dalam pembelajaran } \\
\text { fisika melalui penerapan } \\
\text { Pendidikan STEM }\end{array}$ & $\begin{array}{l}\text { Fluida static } \\
\text { dan fluida } \\
\text { dinamik }\end{array}$ & $\begin{array}{l}\text { Sekolah } \\
\text { Menengah Akhir }\end{array}$ & E-Learning \\
\hline
\end{tabular}

\section{HASIL DAN PEMBAHASAN}

\section{HASIL}

Menurut Sung dan Hwang, pembelajaran berbasis permainan merupakan permainan yang diintegrasikan dalam pembelajaran dan adanya kolaborasi antar peserta didik untuk menyusun ilmu selama proses pembelajaran (Weng et al., 2018). Khususnya permainan digital, Osman (dalam, Weng et.al., 20118) menjelaskan permainan komputer dalam Pendidikan Kimia dapat menyediakan suatu wadah untuk mengembangkan kemampuan peserta didik untuk mempraktikkan kemampuan abad ke21 dan mencapai tujuan pembelajaran Kimia. Selain itu juga, kegiatan PBP ini meningkatkan keaktifan peserta didik selama pembelajaran dan sifat inkuiri.

Selain itu, permainan video terhadap pembelajaran konsep kinematika dan dinamika dapat meningkatkan pemikiran visual selama proses pembelajaran konsep fisika. Dalam kajian Biologi yang dilakukan Sadler et al. (dalam(Weng et al., 2018)) khususnya pada topik bioteknologi dapat dilakukan untuk semua kalangan pelajar. Dalam bidang kimia, Bayir melakukan penelitian tahun 2014 mengenai persepsi pendidik menggunakan permainan digital dapat meningkatkan motivasi belajar dan peserta didik bukan menghafal konsep tetapi memahami dan dapat menerapkannya pada kehidupan seharihari.(Weng et al., 2018). Pembelajaran berasaskan permainan sangatlah penting karena dapat mengembangkan kemampuan abad 21 peserta didik, seperti kolaborasi, komunikasi, berpikir kritis, kreatif, dan komputasional.

Penelitian yang lainnya menemukan suatu masalah dalam mengajarkan IPA karena pembelajaran IPA terdiri dari pemahaman konsep, prinsip, teori dan proses sains melalui praktikum. Untuk kegiatan praktikum, jarang dilakukan oleh guru karena ada berbagai hambatan, seperti kurangnya alat praktikum yang disediakan sekolah dan kurang nya pemahaman cara kerja di laboratorium (Adisendjaja dan 
Analisis Literatur Teknologi...

Romlah dalam (Ismail et al., 2016). Peneliti menemukan salah satu solusinya yaitu dengan adanya virtual lab yang dapat digunakan sebagai pengganti praktikum yang tidak bisa diakukan secara langsung.

Menurut Herga, Gmerk, dan Dinevski dalam (Ismail et al., 2016) menyebutkan beberapa manfaat dari virtual lab, yaitu (1) memberikan kesempatan kepada siswa untuk melakukan eksperimen yang lain secara efektif dari segi waktu dan biaya, (2) adanya visualisasi yang membuat peserta didik lebih memahami konsep yang makroskopik, submikroskopik, dan simbolik, (3) memberikan presentasi dinamis dari bidang partikel submikro,(4) berkontribusi dalam pemahaman konsep, dan (5) sebagai motivasi untuk peserta didik.

Ismail et al. (2016) melakukan penelitian dengan menggunakan virtual lab berbasis STEM dengan tema pencemaran air karena merupakan tema yang bersifat mikroskopis. Penelitian diawali dengan pretest, lalu dilanjutkan dengan pembelajaran menggunakan virtual lab berbasis STEM sebanyak tiga kali dengan tema tingkat kekeruhan air, $\mathrm{pH}$ air, dan kandungan bakteri patogen pada air, dan diakhiri dengan dilakukan posttest.

Efektivitas lab virtual yang berbasis STEM dikatakan efektif digunakan, jika adanya peningkatan literasi sains peserta didik. Berdasarkan hasil penelitiannya, ditemukan bahwa virtual lab yang berbasis STEM mengenai pencemaran air ini efektif dikarenakan adanya peningkatan literasi sains peserta didik baik laki-laki maupun perempuan

(Asri et al., 2021) melakukan penelitian pembelajaran jarak jauh dengan pendekatan STEM pada materi listrik. Pembelajaran dilakukan melalui video conference dan tugas terstruktur. Mereka menemukan, dalam bidang sains, peserta dididik memahami konsep dasar, hukum dan persamaan yang digunakan. Dalam bidang teknologi, penentuan teknologi yang digunakan dari mual perancangan prototipe sampai terbentuk. Dalam bidang engineering, evaluasi proses pembuatan prototipe. Dalam bidang matematika peserta didik dapat menganalisis pekerjaan mereka secara kuantitatif,

Berdasarkan hasil penelitian, menunjukkan bahwa pembelajaran IPA dapat diintegrasikan dengan Pendidikan STEM dalam pembelajaran jarak jauh dengan memberikan tugas terstruktur. Walaupun, 90\% peserta didik dapat mengikuti pembelajaran pada bidang sains, teknologi dan engineering, tapi untuk matematika masih kurang dari setengahnya. Sehingga, diperlukan evaluasi disetiap bidang bukan hanya di akhir pembelajaran.

Selain itu, peningkatan keterampilan ilmiah peserta didik dalam pembelajaran fisika melalui penerapan pendekatan STEM dan e-learning diperoleh dari penelitian (Agung et al., 2018). Menurut Mayasari (Agung et al., 2018) pembelajaran STEM mengembangkan kemampuan literasi sains dan teknologi dalam memecahkan masalah di kehidupan sehari-hari. (Agung et al., 2018) melakukan penelitian tindakan dengan melakukan pembelajaran fisika pada materi fluida statik dan dinamik. Penelitian dilakukan dengan dua siklus. Siklus pertama diawali dengan pengumpulan informasi melalui internet, menganalisis video, dan diskusi pada forum di LMS. Selanjutnya, pada siklus ke dua, melakukan kegiatan literasi digital pada siklus I dengan penambahan pengunggahan video praktikum berkelompok dimana peserta didik dituntut untuk memiliki literasi digital lebih tinggi. Berdasarkan hasil penelitian didapatkan keterampilan ilmiah peserta didik meningkat dan memberikan respon positif pada kegiatan yang dilaksanakan.

Pada penelitian ini juga diperoleh bahwa pendekatan STEM dan e-learning yang dilakukan harus memperhatikan beberapa hal, seperti pemilihan praktikum berdasarkan kebutuhan peserta didik, penerapan e-learning diarahkan kepada aktivitas fisik bukan hanya menonton video, adanya pendampingan peserta didik selama proses pembelajaran supaya terarahkan dalam aktivitas STEM, dan peserta didik dilibatkan dalam penyusunan kelengkapan pembelajaran.

\section{PEMBAHASAN}

Berdasarkan penelitian-penelitian yang telah dilakukan mengenai pemanfaatan teknologi dalam pembelajaran IPA yang terintegrasi STEM, semuanya telah menggunakan teknologi sebagai bagian 
Analisis Literatur Teknologi...

dari aktivitas kelas. Pemanfaatan teknologi yang diterapkan mulai dari sebagai alat pendukung kelas sampai dilibatkan untuk mencapai kompetensi yang ditentukan. Salah satu pemanfaatan teknologi yang telah dilakukan yaitu dalam pembelajaran berbasis permainan yang dimana peserta didik dituntut untuk menciptakan suatu permainan yang berdasarkan konsep IPA. Pembuatan permainan game merupakan salah satu tujuan dari Pendidikan STEM yang mana peserta didik dapat menciptakan suatu produk sebagai solusi suatu masalah. Selain pembuatan game meningkatkan kemampuan berpikir kritis, inovatif dan kreatif, pada penelitian ini kemampuan kolaborasi juga dilibatkan karena siswa tidak hanya membuat produk ini sendiri, melainkan bersama kelompoknya.

Penelitian yang kedua yaitu pemanfaatan virtual lab yang berawal dari kesulitan guru untuk melakukan praktikum secara langsung. Virtual lab digunakan sebagai media untuk mengumpulkan informasi atau data dalam praktikum. Dengan kata lain, teknologi dalam pembelajaran digunakan sebagai media pendukung untuk mengumpulkan informasi. Keterampilan peserta didik dalam mengumpulkan informasi termasuk pada kemampuan pendekatan saintifik. Selain itu, peneliti mengkorelasikan antara kemampuan literasi digital dengan penggunaan virtual lab dan diperoleh bahwa keefektifan penggunaan virtual lab tergantung pada kemampuan literasi digital yang dimiliki peserta didik.

Penelitian yang ketiga dilakukan untuk menganalisis pembelajaran STEM pada pembelajaran jarak jauh. Pada penelitian ini, teknologi digunakan sebagai media pendukung dalam memberikan informasi mengenai materi yang diajarkan. Selain itu, teknologi juga digunakan sebagai media untuk mengembangkan kemampuan peserta didik dalam menciptakan suatu produk setelah melalui proses pembelajaran STEM.

Penelitian yang terakhir dilakukan untuk menganalisis keterampilan ilmiah peserta didik dalam pembelajaran Fisika dengan mengintegrasikan STEM melalui e-learning. Pada aktivitas belajar terdiri dari dua siklus pembelajaran. Pada siklus pertama, teknologi yang digunakan yaitu video dan internet untuk mengumpulkan informasi dan learning management systems sebagai media untuk berdiskusi antar kelompok. Pada siklus kedua, peserta didik dituntut untuk membuat video praktikum fisika. Pada penelitian ini, teknologi digunakan sebagai salah satu media pendukung dalam pembelajaran untuk mencapai kompetensi fisika, meningkatkan keterampilan ilmiah, yaitu mengumpulkan informasi, dan literasi digital dalam membuat suatu produk video praktikum. Dari ketiga penelitian yang dikaji dan dianalisis, dapat dikatakan bahwa teknologi dimanfaatkan sebagai media pendukung dalam mencapai kompetensi pada pelajaran IPA, meningkatkan kemampuan abad 21 dan mengembangkan keterampilan ilmiah.

\section{PENUTUP}

Pemanfaatan teknologi dalam pembelajaran IPA yang terintegrasi STEM dapat mencapai kompetensi pelajaran IPA dan meningkatkan kemampuan abad ke 21. Namun, penggunaan teknologi masih dalam skala sebagai media pendukung kegiatan pembelajaran di kelas, bukan suatu kompetensi yang perlu dicapai oleh peserta didik. Untuk penelitian selanjutnya, diperlukan adanya studi mengenai pembelajaran IPA yang terintegrasi STEM untuk mencapai kompetensi pada bidang teknologi.

\section{DAFTAR PUSTAKA}

Agung, G., Wibowo, W., Peningkatan, ), IImiah, K., Didik, P., Fisika, P., Penerapan, M., Stem Dan ELearning, P., Negeri, S., \& Mandara, B. (2018). Peningkatan Keterampilan Ilmiah Peserta Didik dalam Pembelajaran Fisika Melalui Penerapan Pendekatan STEM dan E-Learning. Journal of Education Action Research, 2(4), 315-321. https://ejournal.undiksha.ac.id/index.php/JEAR/index Asri, Y. N., Mursyidah, D. S., \& Rizqi, V. (2021). Analysis of STEM Approaches through Distance Learning. EDUCATIO : Journal Of Education, 6(2). 
Analisis Literatur Teknologi...

Banks, Frank, Barlex, \& David. (2014). Teaching STEM in the Secondary School. Routledge.

Ismail, I., Permanasari, A., \& Setiawan, W. (2016). Efektivitas virtual lab berbasis STEM dalam meningkatkan literasi sains siswa dengan perbedaan gender. Jurnal Inovasi Pendidikan IPA, 2(2), 190. https://doi.org/10.21831/jipi.v2i2.8570

Milaturrahmah, N., Mardiyana, \& Pramudya, I. (2017). Science, technology, engineering, mathematics (STEM) as mathematics learning approach in 21st century. AIP Conference Proceedings, 1868. https://doi.org/10.1063/1.4995151

Rahmaniar, A. (2020). Perceptions Of The Indonesia National Curriculum In Relation To Perceptions Of The Indonesia National Curriculum In Relation To Integrated Stem Education At The High School Level Integrated Stem Education At The High School Level. https://ir.library.illinoisstate.edu/etd/1341

Weng, W., Smk, S., Paul, S., \& Osman, K. (2018). Pembelajaran Berasaskan Permainan dalam Pendidikan Stem dan Penguasaan Kemahiran Abad Ke-21. In Politeknik \& Kolej Komuniti Journal of Social Sciences and Humanities (Vol. 3).

Wilson., H. W. (2019). STEM 4: The power of collaboration for change A joint document authored by Advance CTE, Association of State Supervisors of Mathematics, Council of State Science Supervisors, and International Technology and Engineering Educators Association Advance CTE - ASSM • CSSS • ITEEA. 